\title{
Temporally Coherent Visual Stimuli Boost Ocular Dominance Plasticity
}

\author{
Ulrike Matthies, Jenny Balog, and Konrad Lehmann \\ Institut für Allgemeine Zoologie and Tierphysiologie, Friedrich Schiller Universität Jena, 07743 Jena, Germany
}

Does cortical plasticity depend on the temporal coherence of visual stimuli? We addressed this question by studying ocular dominance (OD) plasticity in mice that were stimulated by moving square wave gratings for $6 \mathrm{~h} / \mathrm{d}$ during a period of monocular deprivation (MD). It turned out that $4 \mathrm{~d}$ of deprivation were sufficient to induce a saturated shift in plasticity in adult (older than postnatal day 100) mice. Seeking to determine the shortest effective period of stimulation, we further showed that even $2 \mathrm{~d}$ of deprivation and stimulation shifted $\mathrm{OD}$ at any age. This shift was achieved by a decline in deprived-eye input that was saturated within $2 \mathrm{~d}$ and did not change during $7 \mathrm{~d}$ of MD. However, after 2 weeks of MD, cortical activity induced by both eyes increased again and this increase did not depend on continued stimulation, suggesting a homeostatic mechanism. Starting stimulation $4 \mathrm{~d}$ before MD did not mask OD plasticity, showing that the effect is not merely due to the "stimulus-dependent response potentiation" described recently (Frenkel et al., 2006). These results are the first to demonstrate the influence of stimulus quality on cortical plasticity and that cortical responses can be changed within very short periods of time (merely $2 \mathrm{~d}$ ).

\section{Introduction}

Learning depends on the interaction between two sides: the stimulus being learned and the system that does the learning. Obviously, the neurosciences have traditionally focused on the system side. Therefore, the neuronal mechanisms that trigger the critical period of ocular dominance (OD) plasticity have been thoroughly and successfully investigated (Hensch, 2004; Sugiyama et al., 2008). In this paradigm, temporal closure of one eye (socalled monocular deprivation [MD]) shifts the susceptibility of the binocular visual cortex toward stimulation of the open eye (Wiesel and Hubel, 1963). Whereas $4 \mathrm{~d}$ of deprivation are sufficient for a maximal effect in mice during the critical period between postnatal days (PDs) 20 and 32 (Gordon and Stryker, 1996), $7 \mathrm{~d}$ are needed beyond that period until plasticity ceases completely around PD 100 (Lehmann and Löwel, 2008).

An increased inhibition exerted by the maturation of parvalbumin-expressing basket interneurons has been shown to trigger this critical period (Hensch et al., 1998; Fagiolini and Hensch, 2000). In addition, the composition of NMDA receptors is changed at the start of the critical period (Quinlan et al., 1999; Roberts and Ramoa, 1999; Kanold et al., 2009). Indeed, longterm potentiation and depression happening at NMDA receptors is crucial for OD plasticity to occur (Kleinschmidt et al., 1987; Sawtell et al., 2003; Sato and Stryker, 2008). Recent results suggest

\footnotetext{
Received Sept. 6, 2012; revised May 30, 2013; accepted June 8, 2013.

Author contributions: K.L. designed research; U.M., J.B., and K.L. performed research; U.M. and K.L. analyzed data; K.L. wrote the paper.

We thank Professor Jürgen Bolz for support and helpful discussions, Sandra Clemens for excellent animal care, and Annika Döding and Céline Heng for proofreading this manuscript.

The authors declare no competing financial interests.

Correspondence should be addressed to PD Dr. Konrad Lehmann, Institut für Allgemeine Zoologie and Tierphysiologie, Erbertstr. 1, D-07743 Jena, Germany. E-mail: Konrad.Lehmann@uni-jena.de.

DOI:10.1523/JNEUROSCI.4262-12.2013

Copyright $\odot 2013$ the authors $\quad 0270-6474 / 13 / 3311774-05 \$ 15.00 / 0$
}

that the Hebbian plasticity underlying the shift in OD follows a symmetric spike-timing-dependent plasticity (STDP) rule in which temporally coherent input from the open eye wins over the more disorganized deprived-eye input (Yazaki-Sugiyama et al., 2009; Kuhlman et al., 2010). Indeed, the spontaneous activity reaching the visual cortex from a deprived eye is a more potent inductor of OD plasticity than an eye completely silenced by tetrodotoxin (Rittenhouse et al., 1999). Even more intriguingly, induction of a monocular blur by a translucent contact occluder (Wiesel and Hubel, 1963) or an overcorrecting contact lens (Rittenhouse et al., 2006) induces a similar OD shift in kittens as MD. Similarly, we have shown recently that in quivering mice with impaired myelination and thus impaired action potential propagation along the optic nerve (Yang et al., 2004), the time window for adult OD plasticity closes earlier, before PD 100 (Lehmann et al., 2010). These results inspired us to ask the reverse question: would it be possible to boost OD plasticity by presenting the animals with highly temporally coherent visual input? We here report that stimulation with moving square gratings during the deprivation period enables full OD plasticity in animals of all ages, even after $2 \mathrm{~d}$ of deprivation.

\section{Materials and Methods}

Animals and rearing conditions. Male C57BL/6 mice were raised in standard cages on a $12 \mathrm{~h}$ light/dark cycle, with food and water available ad libitum. All experimental procedures were performed according to the German Law on the Protection of Animals and the corresponding European Communities Council Directive of November 24, 1986 (86/ 609/EEC) and were approved by the Thüringer Landesamt für Lebensmittelsicherheit und Verbraucherschutz (Thuringia State Office for Food Safety and Consumer Protection) under the registration number $02-027 / 11$.

$M D$ and stimulation protocol. The animals' right eyes were sutured shut under halothane anesthesia according to published protocols (Gordon 

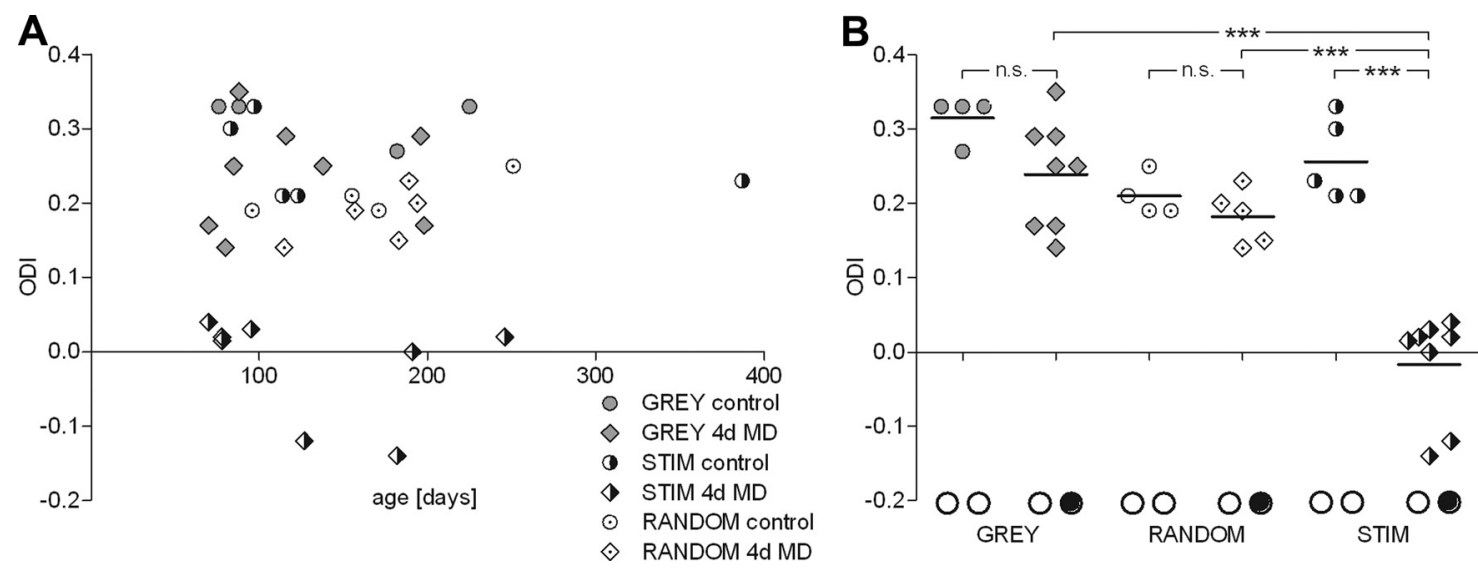

Figure 1. Temporally coherent visual stimulation during MD induces $O D$ plasticity in mice regardless of age. $A$, From 70 to $246 \mathrm{~d}$ of age, $4 \mathrm{~d}$ of MD had no influence on $0 D$ in mice exposed to gray screens (GREY, gray diamonds) or randomly moving circles (RANDOM, dotted diamonds), but shifted it toward the open eye in mice stimulated with drifting square-wave gratings (STIM, black-and-white diamonds). Control animals of all conditions (circles) were similar over age. $\boldsymbol{B}$, Temporally coherent visual stimulation during $4 \mathrm{~d}$ of MD induced a shift in $0 \mathrm{D}$ that was significant compared with control animals and with MD animals in the GREY and RANDOM conditions.

and Stryker, 1996). Animals in which the eye was not completely closed throughout the deprivation period were excluded.

During the deprivation period, the animals were placed for $6 \mathrm{~h} / \mathrm{d}$ during the daylight hours into a stimulation box that consisted of 4 monitors with closed floor and ceiling. Two neighboring monitors were covered with mirrors. For animals in the stimulation (STIM) group, the 2 open monitors showed square black and white gratings with a cycle length of $8.2 \mathrm{~cm}$ and a drift speed of $1 \mathrm{~Hz}$, moving horizontally on one screen and vertically on the other. Therefore, due to the mirrors, these animals were stimulated by bars moving left, right, and upward. Two control groups were investigated. For animals in the GREY group, the screens showed equiluminescent gray, thus avoiding any visual stimulation. For animals in the RANDOM group, the screens showed filled white circles with diameters between 1 and 4 $\mathrm{cm}$ that zigzagged randomly on a black background. Movement speed and mean black/white ratio were matched to the gratings in the STIM group, thus proving an equal degree of visual stimulation that only lacked temporal coherence.

Optical imaging. Using the imaging method of temporally encoded maps (Kalatsky and Stryker, 2003), visual cortical responses in the left hemisphere were recorded as described previously (Lehmann and Löwel, 2008; Yeritsyan et al., 2012) under halothane $\left(1 \%\right.$ in $\left.1: 1 \mathrm{O}_{2} / \mathrm{N}_{2} \mathrm{O}\right)$ anesthesia, supplemented by chlorprothixene $(0.2 \mathrm{mg} /$ mouse, i.m. $)$, atropine $(0.3 \mathrm{mg} / \mathrm{mouse}$, s.c. $)$, and dexamethasone $(0.2 \mathrm{mg} / \mathrm{mouse}$, s.c. $)$. With a $135 \mathrm{~mm} \times 50 \mathrm{~mm}$ tandem lens (Nikon) configuration, we recorded optical images of intrinsic signals in a cortical area of $4.6 \times 4.6 \mathrm{~mm}^{2}$ at a wavelength of $610 \pm 3 \mathrm{~nm}$.

Horizontal drifting bars $\left(2^{\circ}\right.$ wide $)$ spaced $80^{\circ}$ apart were presented at a temporal frequency of $0.125 \mathrm{~Hz}$ in the binocular visual field of the recorded left hemisphere $\left(-5^{\circ}\right.$ to $+15^{\circ}$ azimuth $)$ in front of the animal. Visual stimuli were presented alternately to the left and right eye. ODIs were calculated as described previously (Cang et al., 2005; Lehmann and Löwel, 2008). Briefly, activity maps were thresholded at 30\% of peak amplitude and OD was calculated for each pixel in the binocularly responsive region as (contralateral - ipsilateral)/(contralateral + ipsilateral) and averaged across all selected pixels. At least three ODIs per animal were obtained and averaged; experiments with less than three ODIs were discarded. As a measurement of each eye's ability to excite the cortex, the highest map amplitude (i.e., fractional change in reflectance) elicited in an experiment was used for comparison.

Statistical analyses. Groups were compared by ANOVA with repeated measures where appropriate. Post hoc tests were performed with Bonferroni correction. The levels of significance were set as ${ }^{\star} p<0.05$, ${ }^{* *} p<$ 0.01 , and ${ }^{* *} p<0.001$. All data are represented as means \pm SEM.

\section{Results}

Temporally coherent visual stimulation promotes adult OD plasticity

Mice were stimulated with moving square gratings (STIM group), randomly moving filled circles (RANDOM group), or equiluminescent gray (GREY group) during $4 \mathrm{~d}$ of MD starting at an age between PD 70 and PD 246. Control ODIs were stable over the age range studied ( $p>0.5$ in all groups, regression analysis). On average, control ODIs were $0.32 \pm 0.02(n=4)$ in the GREY group, $0.21 \pm 0.01(n=4)$ in the RANDOM group, and $0.26 \pm$ $0.02(n=5)$ in the STIM group (Fig. $1 A, B)$. Control groups were different according to ANOVA $(p<0.05)$, with a significant difference between the GREY and the RANDOM groups $(p<$ 0.05, Bonferroni post hoc), but none of the two differed from the STIM group $(p>0.18)$. Although it was shown recently that adult OD plasticity ceases abruptly after PD 100 in mice (Lehmann and Löwel, 2008), ODIs after $4 \mathrm{~d}$ of MD were also not correlated with age in the 3 groups (STIM: $p=0.49$, RANDOM: $p=0.13$, GREY: $p=0.86$ ), allowing us to disregard age in further analyses (Fig. $1 A$ ). Four days of MD had no effect on OD in the GREY group $(0.24 \pm 0.03, n=8, p>0.2, t$ test $)$ or the RANDOM group $(0.18 \pm 0.02, n=5, p>0.25, t$ test $)$. In contrast, ODIs decreased significantly $(p<0.001, t$ test $)$ to $-0.02 \pm 0.03$ in the STIM group $(n=8)$, which is also significantly different from both the deprived GREY and RANDOM animals (both $p<$ $0.001, t$ test).

\section{Two days of MD induce a saturated shift of OD in stimulated mice}

We next investigated the minimal period of MD needed for a saturated OD shift in STIM mice. MD duration had a significant effect on ODI $\left(F_{(5,19)}=20.323, p<0.001\right.$, ANOVA $)$. Although the mean ODI of $0.21 \pm 0.04(n=2)$ after $1 \mathrm{~d}$ of MD was not significantly different from control values $(p>0.5$, Bonferronicorrected $t$ test), the ODI decreased to $-0.04 \pm 0.02(n=3)$ after $2 \mathrm{~d}$ of deprivation $(p<0.001$ vs control) and was not significantly lower after $4 \mathrm{~d}(-0.02$, see above), $7 \mathrm{~d}$ (ODI $=0 \pm 0.03, n=4$, $p<0.001$ vs control), or $14 \mathrm{~d}(\mathrm{ODI}=0.08 \pm 0.01, n=3, p<0.01$ vs control) of MD (Fig. 2). The mean values of the 2,4 , and $7 \mathrm{~d}$ MD groups were significantly below the $1 \mathrm{~d}$ MD value $(p<0.01$, Bonferroni-corrected $t$ test). 


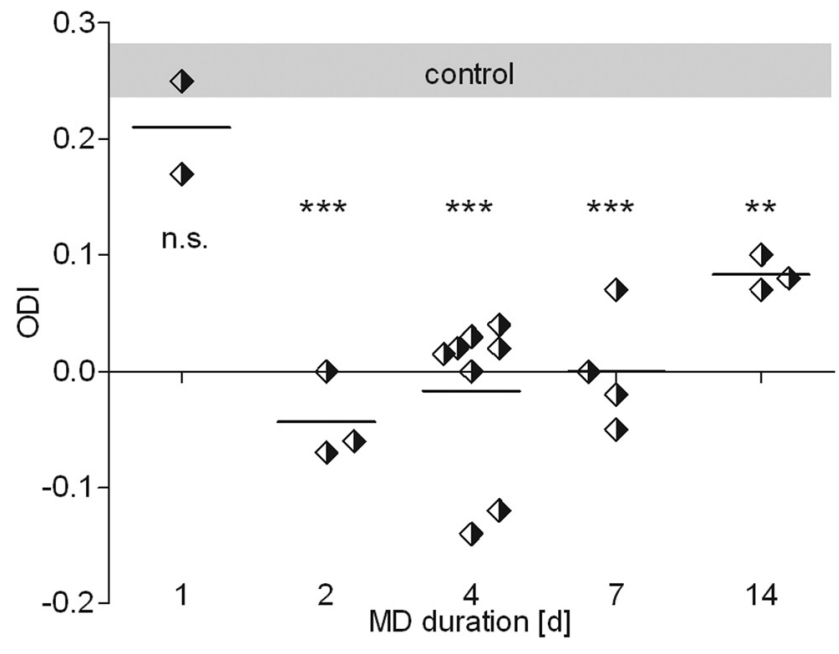

Figure 2. Two days of MD induce a saturated OD shift in adult mice stimulated with moving square gratings. The gray bar indicates mean \pm SEM of control animals.

\section{Visual stimulation induces deprived-eye depression followed by open-eye potentiation}

The mechanisms of OD plasticity differ between the critical period and adulthood (Sawtell et al., 2003; Sato and Stryker, 2008; Ranson et al., 2012): During the critical period, responses elicited through the deprived eye are quickly reduced, which is followed by a slower potentiation of open-eye responses. Adult plasticity is characterized by a slow increase in open-eye input, although deprived-eye depression has also been observed in the contralateral (Frenkel et al., 2006) and ipsilateral (Tagawa et al., 2005) cortices. We therefore investigated how the OD shift was achieved in STIM mice. Comparison of the response amplitudes elicited by each eye showed that, starting at $2 \mathrm{~d}$ of $\mathrm{MD}$, the average response amplitudes of the deprived, contralateral eye were significantly reduced to open-eye values and remained on this level even after 4 and $7 \mathrm{~d}$ of MD (Fig. 3; $2 \mathrm{~d}$ of MD: $p<0.05$; $4 \mathrm{~d}$ of MD: $p<0.01 ; 7 \mathrm{~d}$ of MD: $p<0.05$, Bonferroni post test). In contrast, response amplitudes to open-eye stimulation did not change after $7 \mathrm{~d}$ of MD.

After 14d MD, we found the response amplitudes elicited by either eye to be increased compared with pooled 2, 4, and $7 \mathrm{~d}$ values (both $p<0.05, t$ test), and this increase was also significant for ipsilateral eye values compared with control animals $(p<$ $0.05, t$ test). To determine whether this open-eye potentiation depended on continued visual stimulation, we stimulated a group with moving gratings for $4 \mathrm{~d}$ after the start of MD to induce an OD shift and then kept them in the GREY condition for another $10 \mathrm{~d}$ of MD. In these animals, cortical activities elicited by both eyes increased to similar values as in the $14 \mathrm{~d}$ STIM group (both $p>0.2, t$ test). The potentiation of open-eye responses was significant compared with the pooled 2,4 , and $7 \mathrm{~d}$ values $(p<$ $0.05, t$ test).

In control animals, response amplitudes were $(2.0 \pm 0.3) \times$ $10^{-4}$ for contralateral and $(1.3 \pm 0.1) \times 10^{-4}$ for ipsilateral eye stimulation. Contralateral eye responses declined to (1.8 \pm $0.1) \times 10^{-4}$ after $1 \mathrm{~d}$ of MD; $(1.3 \pm 0.3) \times 10^{-4}$ after $2 \mathrm{~d}$ of MD; $(1.3 \pm 0.1) \times 10^{-4}$ after $4 \mathrm{~d}$ of MD; and $(1.4 \pm 0.2) \times 10^{-4}$ after $7 \mathrm{~d}$ of MD. After $14 \mathrm{~d}$ of MD, contralateral eye responses increased to $(1.9 \pm 0.2) \times 10^{-4}$ in the STIM group and to $(1.6 \pm$ $0.1) \times 10^{-4}$ in the STIM-GREY group. Ipsilateral eye responses were stable at $(1.4 \pm 0.03) \times 10^{-4}$ after $1 \mathrm{~d}$ of MD; $(1.3 \pm 0.2) \times$ $10^{-4}$ after $2 \mathrm{~d}$ of $\mathrm{MD}$; $(1.3 \pm 0.1) \times 10^{-4}$ after $4 \mathrm{~d}$ of $\mathrm{MD}$; and
$(1.3 \pm 0.2) \times 10^{-4}$ after $7 \mathrm{~d}$ of $\mathrm{MD}$; after $14 \mathrm{~d}$ of $\mathrm{MD}$, they increased to $(1.7 \pm 0.05) \times 10^{-4}$ and $(1.8 \pm 0.4) \times 10^{-4}$ in the STIM and the STIM-GREY groups, respectively.

\section{Enhanced plasticity under visual stimulation is not due to stimulus-dependent response potentiation}

It was shown recently that exposing mice to moving square gratings persistently potentiates the cortical response to gratings of the same orientation and this potentiation interferes with changes in OD if only one eye is stimulated (Frenkel et al., 2006). We wondered whether this learning process, termed "stimulusdependent response potentiation" (SRP), could account for the OD shift that we observed after visual stimulation of the open eye. The observation that this OD shift was achieved by a decrease in deprived-eye input throughout all MD durations (Fig. 2) already argued against this supposition, because an enhancement of open-eye input would have been expected upon SRP. Nevertheless, to further exclude the possibility of SRP, we exposed mice to temporally coherent visual stimulation for $4 \mathrm{~d}$ before $\mathrm{MD}$ and then continued stimulation for another $4 \mathrm{~d}$ until optical recording was performed. OD plasticity was not masked in these animals (Fig. 4A). Their mean ODI of $0.04 \pm 0.01(n=6)$ was still significantly below control values $(p<0.001, t$ test, same control animals as in Fig. 1).

As an additional check for a role of SRP, we compared the response amplitudes upon stimulation of both eyes among control animals of the GREY, RANDOM, and STIM groups (Fig. 4B). The values were $(2.4 \pm 0.24) \times 10^{-4}($ contralateral $)$ and $(1.3 \pm 0.17) \times$ $10^{-4}$ (ipsilateral) in GREY animals $(n=4) ;(1.9 \pm 0.22) \times 10^{-4}$ (contralateral) and $(1.5 \pm 0.16) \times 10^{-4}$ (ipsilateral) in RANDOM animals; and $(2 \pm 0.33) \times 10^{-4}$ (contralateral) and $(1.3 \pm 0.1) \times$ $10^{-4}$ (ipsilateral) in STIM animals $(n=5)$. Comparison by twofactor ANOVA revealed no significant difference $\left(F_{(2,20)}=0.398\right.$, $p=0.68)$, indicating that our stimulation protocol by itself was not capable of inducing a response potentiation observable by optical imaging.

\section{Discussion}

We have shown in the present study that an OD shift can be induced by temporally coherent visual stimuli in adult mice. Temporally incoherent but otherwise similar stimuli had no effect on OD. That visual stimulation as a component of enriched environments leads to an OD shift in amblyopic rats and to recovery of the deprived eye from amblyopia has been shown recently (Sale et al., 2007; Baroncelli et al., 2012). In that study, however, rats were stimulated for 3 weeks. In contrast, we have shown here that $2 \mathrm{~d}$ of stimulation are sufficient for an effect on $\mathrm{OD}$ at any age.

The mechanisms of OD plasticity differ between the critical period and adulthood (Frenkel and Bear, 2004; Hofer et al., 2006; Sato and Stryker, 2008; Ranson et al., 2012). During the critical period, weakening of deprived-eye input is followed by strengthening of open-eye input (Frenkel and Bear, 2004; Sato and Stryker, 2008). In adult animals, strengthening of open-eye input has been observed the most frequently (Sawtell et al., 2003; Hofer et al., 2006; Sato and Stryker, 2008), although some studies also found evidence for additional deprived-eye depression (Tagawa et al., 2005; Frenkel et al., 2006). In the present study, the OD shift was initially reached by a decrease in activity coming from the deprived eye, thus resembling critical period plasticity although the animals were fully adult.

The weakening of deprived-eye input that forms the first phase of critical period OD plasticity has been shown to rely on 


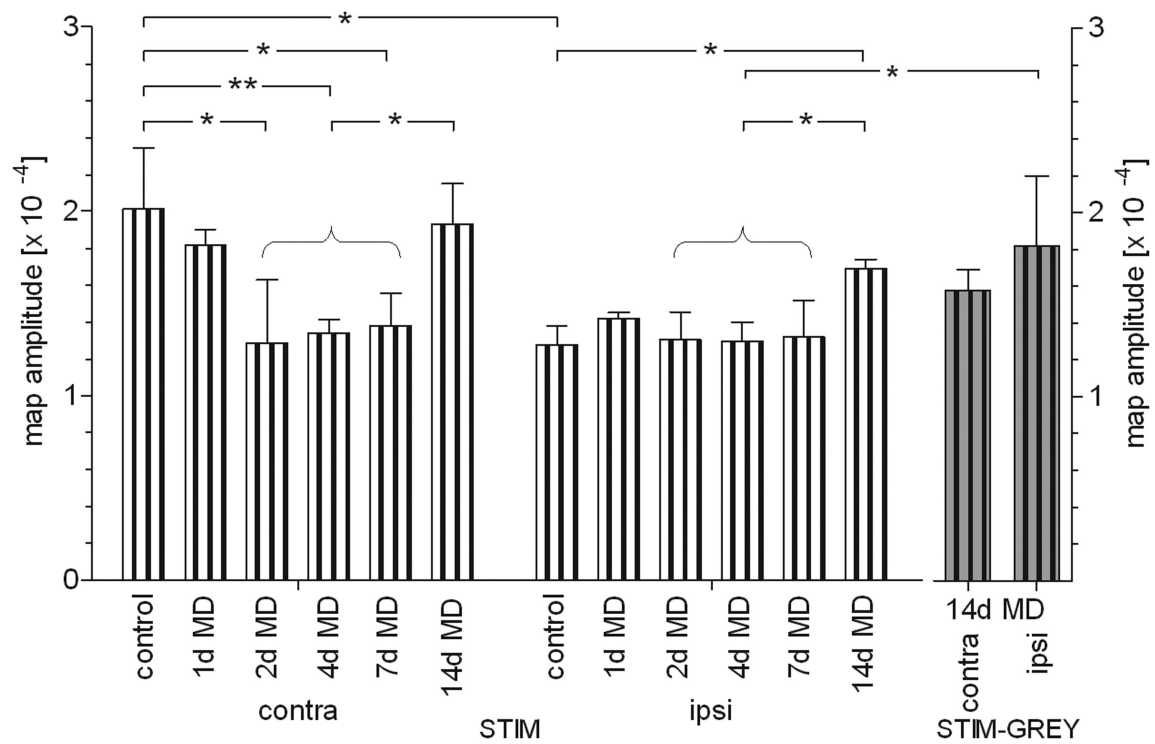

Figure 3. The OD shift induced by temporally coherent visual stimulation (black/white bars) is achieved by weakening of deprived-eye input starting after $2 \mathrm{~d}$ of MD. This is followed by strengthening of both eyes after $14 \mathrm{~d}$ of MD regardless of whether stimulation was continued (STIM) or discontinued (STIM-GREY, black/gray bars) after $4 \mathrm{~d}$.
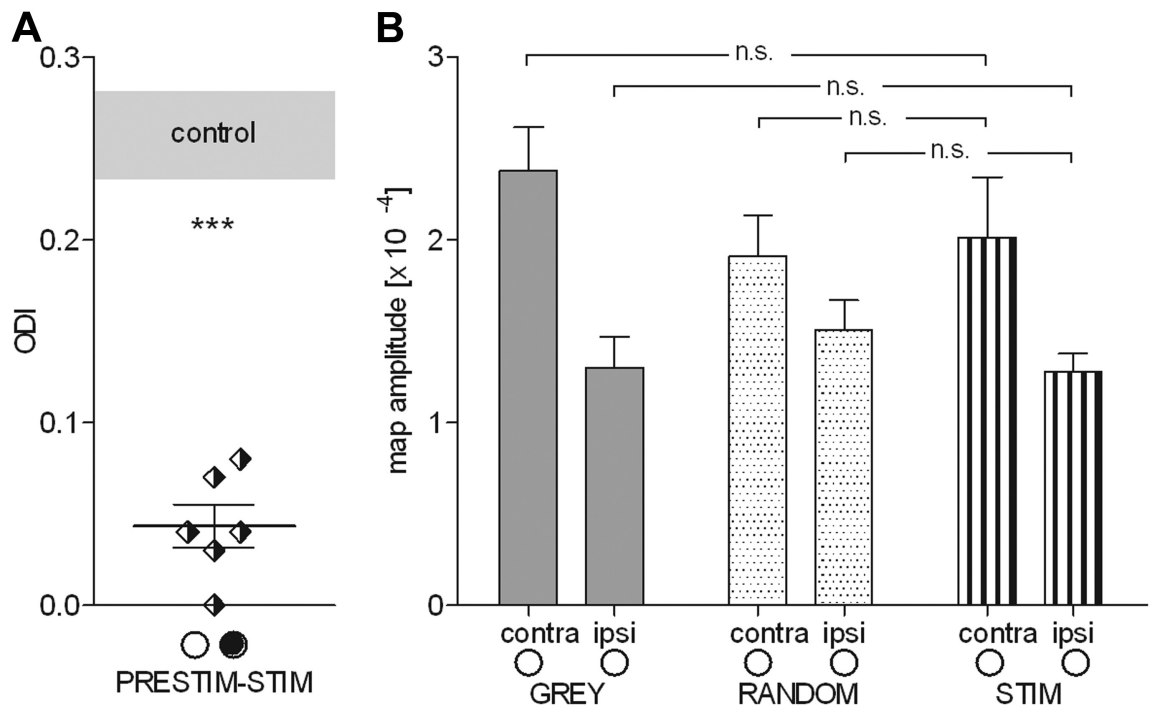

Figure 4. Prior stimulation does not mask stimulation-induced plasticity. $\boldsymbol{A}$, Monocularly deprived mice stimulated both before and after the MD (PRESTIM-STIM) show a significant shift in OD. The gray bar indicates mean \pm SEM of control animals. $\boldsymbol{B}$, Cortical response amplitudes upon stimulation of both the contralateral (contra) and the ipsilateral (ipsi) eye are similar in GREY, RANDOM, and STIM control animals.

long-term depression expressed by AMPA receptor dephosphorylation and internalization (Heynen et al., 2003; Yoon et al., 2009). Long-term depression in the visual cortex depends on both the rate and the timing of action potentials (i.e., on STDP; Sjöström et al., 2001). It has been shown in vivo that STDP modifies synapses in the visual cortex (Schuett et al., 2001; Meliza and Dan, 2006). Furthermore, an STDP learning rule can explain both the shift of fast spiking cells' eye preference toward the deprived eye (Yazaki-Sugiyama et al., 2009) and the shift of principal cell preference toward the open eye (Kuhlman et al., 2010). In visual cortical slices, the capacity for STDP is present already before the onset of the critical period (Kuhlman et al., 2010). Our results indicate that it is not lost in adulthood, but lies dormant under normal stimulus conditions.
The fact that visual stimulation paired with intracortical spiking can induce STDP (Schuett et al., 2001; Meliza and Dan, 2006) indicates that the temporal precision of retinal activity is propagated with little change across the lateral geniculate to the visual cortex. Although the relationship between activities in retina, lateral geniculate, and visual cortex is not straightforward, eye closure reduces the correlative firing of pairs of neurons in the dorsal lateral geniculate (Linden et al., 2009), which is a prerequisite for STDP. We therefore assume that the high contrast and temporal patterning of square gratings in our stimulation paradigm are translated into high temporal coherence of afferent spiking in the binocular visual cortex, just as, conversely, monocular blurring of the retinal image reduces temporal coherence, but not illumination, and carries the full consequences of MD (Wiesel and Hubel, 1963; Rittenhouse et al., 2006). Computer modeling work has recently shown that, given a sufficiently strong cortical inhibition, STDP will shift the response preference of a neuron toward the more temporally coherent input (Kuhlman et al., 2010). Our results are the first in vivo proof of this mechanism in OD plasticity.

The second phase of critical period OD plasticity, open eye potentiation, is governed by different, probably homeostatic, mechanisms during the critical period (Mrsic-Flogel et al., 2007; Kaneko et al., 2008). This homeostatic adaptation is replaced by long-term potentiation in adult plasticity (Ranson et al., 2012). In the present study, we observed a late, secondary increase in the cortical response amplitudes upon stimulation of both eyes that was not dependent on visual stimulation. This suggests that the late homeostatic increase is not a distinguishing feature of critical period OD plasticity, but rather is an invariable consequence of a decrease in synaptic strength by Hebbian mechanisms.

In our experiments, cortical activity was not increased by SRP (Frenkel et al., 2006). Because Frenkel et al. (2006) previously found SRP with as little as 100 cycles of contrast-reversing sine gratings $(1 \mathrm{~Hz})$, this negative result is probably not due to our stimulus paradigm, which offers a more structured stimulus for a longer time, but rather to the method used for measuring cortical activity because different forms of visual plasticity recruit different neuronal substrates (Lehmann and Löwel, 2008; for review, see Morishita and Hensch, 2008). Optical imaging is thought to reflect neuronal spiking and peak firing rates were not found to be influenced by SRP (Frenkel et al., 2006).

The amazing capacity of visual stimulation to recover impaired vision has been demonstrated in rats and humans in previous studies (Kasten et al., 1998; Julkunen et al., 2003; Baroncelli 
et al., 2012). Vision loss due to stroke or optical nerve trauma was rescued by a training paradigm in a large fraction of patients (Sabel et al., 2011). Rats with amblyopia showed full recovery after 3 weeks of visual stimulation (Baroncelli et al., 2012). In humans, substantial improvement in amblyopic patients was observed after intense video game playing, but the contribution of neuromodulatory arousal in that case is not clear (Li et al., 2011). In the present study, we have investigated the potential of highly patterned visual stimuli to induce cortical plasticity. Our findings may open perspectives both for clinical applications and for transfer to other sensory modalities.

\section{References}

Baroncelli L, Bonaccorsi J, Milanese M, Bonifacino T, Giribaldi F, Manno I, Cenni MC, Berardi N, Bonanno G, Maffei L, Sale A (2012) Enriched experience and recovery from amblyopia in adult rats: impact of motor, social and sensory components. Neuropharmacology 62:2388-2397. CrossRef Medline

Cang J, Kalatsky VA, Löwel S, Stryker MP (2005) Optical imaging of the intrinsic signal as a measure of cortical plasticity in the mouse. Vis Neurosci 22:685-691. CrossRef Medline

Fagiolini M, Hensch TK (2000) Inhibitory threshold for critical-period activation in primary visual cortex. Nature 404:183-186. CrossRef Medline

Frenkel MY, Bear MF (2004) How monocular deprivation shifts ocular dominance in visual cortex of young mice. Neuron 44:917-923. CrossRef Medline

Frenkel MY, Sawtell NB, Diogo AC, Yoon B, Neve RL, Bear MF (2006) Instructive effect of visual experience in mouse visual cortex. Neuron 51:339-349. CrossRef Medline

Gordon JA, Stryker MP (1996) Experience-dependent plasticity of binocular responses in the primary visual cortex of the mouse. J Neurosci 16: 3274-3286. Medline

Hensch TK (2004) Critical period regulation. Annu Rev Neurosci 27:549579. CrossRef Medline

Hensch TK, Fagiolini M, Mataga N, Stryker MP, Baekkeskov S, Kash SF (1998) Local GABA circuit control of experience-dependent plasticity in developing visual cortex. Science 282:1504-1508. CrossRef Medline

Heynen AJ, Yoon BJ, Liu CH, Chung HJ, Huganir RL, Bear MF (2003) Molecular mechanism for loss of visual cortical responsiveness following brief monocular deprivation. Nat Neurosci 6:854-862. CrossRef Medline

Hofer SB, Mrsic-Flogel TD, Bonhoeffer T, Hübener M (2006) Prior experience enhances plasticity in adult visual cortex. Nat Neurosci 9:127-132. CrossRef Medline

Julkunen L, Tenovuo O, Jääskeläinen S, Hämäläinen H (2003) Rehabilitation of chronic post-stroke visual field defect with computer-assisted training: a clinical and neurophysiological study. Restor Neurol Neurosci 21:19-28. Medline

Kalatsky VA, Stryker MP (2003) New paradigm for optical imaging: temporally encoded maps of intrinsic signal. Neuron 38:529-545. CrossRef Medline

Kaneko M, Stellwagen D, Malenka RC, Stryker MP (2008) Tumor necrosis factor-alpha mediates one component of competitive, experiencedependent plasticity in developing visual cortex. Neuron 58:673-680. CrossRef Medline

Kanold PO, Kim YA, GrandPre T, Shatz CJ (2009) Co-regulation of ocular dominance plasticity and NMDA receptor subunit expression in glutamic acid decarboxylase-65 knock-out mice. J Physiol 587:2857-2867. CrossRef Medline

Kasten E, Wüst S, Behrens-Baumann W, Sabel BA (1998) Computer-based training for the treatment of partial blindness. Nat Med 4:1083-1087. CrossRef Medline

Kleinschmidt A, Bear MF, Singer W (1987) Blockade of "NMDA" receptors disrupts experience-dependent plasticity of kitten striate cortex. Science 238:355-358. CrossRef Medline

Kuhlman SJ, Lu J, Lazarus MS, Huang ZJ (2010) Maturation of GABAergic inhibition promotes strengthening of temporally coherent inputs among convergent pathways. PLoS Comput Biol 6:e1000797. CrossRef Medline

Lehmann K, Löwel S (2008) Age-dependent ocular dominance plasticity in adult mice. PLoS One 3:e3120. CrossRef Medline

Lehmann K, Strenzke N, Wolf F, Löwel S (2010) Impaired ocular domi-

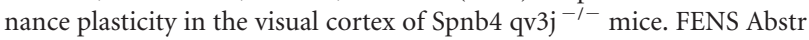
5:081.018.
Li RW, Ngo C, Nguyen J, Levi DM (2011) Video-game play induces plasticity in the visual system of adults with amblyopia. PLoS Biol 9:e1001135. CrossRef Medline

Linden ML, Heynen AJ, Haslinger RH, Bear MF (2009) Thalamic activity that drives visual cortical plasticity. Nat Neurosci 12:390-392. CrossRef Medline

Meliza CD, Dan Y (2006) Receptive-field modification in rat visual cortex induced by paired visual stimulation and single-cell spiking. Neuron 49: 183-189. CrossRef Medline

Morishita H, Hensch TK (2008) Critical period revisited: impact on vision. Curr Opin Neurobiol 18:101-107. CrossRef Medline

Mrsic-Flogel TD, Hofer SB, Ohki K, Reid RC, Bonhoeffer T, Hübener M (2007) Homeostatic regulation of eye-specific responses in visual cortex during ocular dominance plasticity. Neuron 54:961-972. CrossRef Medline

Quinlan EM, Olstein DH, Bear MF (1999) Bidirectional, experiencedependent regulation of $N$-methyl-D-aspartate receptor subunit composition in the rat visual cortex during postnatal development. Proc Natl Acad Sci U S A 96:12876-12880. CrossRef Medline

Ranson A, Cheetham CE, Fox K, Sengpiel F (2012) Homeostatic plasticity mechanisms are required for juvenile, but not adult, ocular dominance plasticity. Proc Natl Acad Sci U S A 109:1311-1316. CrossRef Medline

Rittenhouse CD, Shouval HZ, Paradiso MA, Bear MF (1999) Monocular deprivation induces homosynaptic long-term depression in visual cortex. Nature 397:347-350. CrossRef Medline

Rittenhouse CD, Siegler BA, Voelker CC, Voelker CA, Shouval HZ, Paradiso MA, Bear MF (2006) Stimulus for rapid ocular dominance plasticity in visual cortex. J Neurophysiol 95:2947-2950. CrossRef Medline

Roberts EB, Ramoa AS (1999) Enhanced NR2A subunit expression and decreased NMDA receptor decay time at the onset of ocular dominance plasticity in the ferret. J Neurophysiol 81:2587-2591. Medline

Sabel BA, Henrich-Noack P, Fedorov A, Gall C (2011) Vision restoration after brain and retina damage: the "residual vision activation theory." Prog Brain Res 192:199-262. CrossRef Medline

Sale A, Maya Vetencourt JF, Medini P, Cenni MC, Baroncelli L, De Pasquale R, Maffei L (2007) Environmental enrichment in adulthood promotes amblyopia recovery through a reduction of intracortical inhibition. Nat Neurosci 10:679-681. CrossRef Medline

Sato M, Stryker MP (2008) Distinctive features of adult ocular dominance plasticity. J Neurosci 28:10278-10286. CrossRef Medline

Sawtell NB, Frenkel MY, Philpot BD, Nakazawa K, Tonegawa S, Bear MF (2003) NMDA receptor-dependent ocular dominance plasticity in adult visual cortex. Neuron 38:977-985. CrossRef Medline

Schuett S, Bonhoeffer T, Hübener M (2001) Pairing-induced changes of orientation maps in cat visual cortex. Neuron 32:325-337. CrossRef Medline

Sjöström PJ, Turrigiano GG, Nelson SB (2001) Rate, timing, and cooperativity jointly determine cortical synaptic plasticity. Neuron 32:1149-1164. CrossRef Medline

Sugiyama S, Di Nardo AA, Aizawa S, Matsuo I, Volovitch M, Prochiantz A, Hensch TK (2008) Experience-dependent transfer of Otx2 homeoprotein into the visual cortex activates postnatal plasticity. Cell 134:508-520. CrossRef Medline

Tagawa Y, Kanold PO, Majdan M, Shatz CJ (2005) Multiple periods of functional ocular dominance plasticity in mouse visual cortex. Nat Neurosci 8:380-388. CrossRef Medline

Wiesel TN, Hubel DH (1963) Single-cell responses in striate cortex of kittens deprived of vision in one eye. J Neurophysiol 26:1003-1017. Medline

Yang Y, Lacas-Gervais S, Morest DK, Solimena M, Rasband MN (2004) BetaIV spectrins are essential for membrane stability and the molecular organization of nodes of Ranvier. J Neurosci 24:7230-7240. CrossRef Medline

Yazaki-Sugiyama Y, Kang S, Câteau H, Fukai T, Hensch TK (2009) Bidirectional plasticity in fast-spiking GABA circuits by visual experience. Nature 462:218-221. CrossRef Medline

Yeritsyan N, Lehmann K, Puk O, Graw J, Löwel S (2012) Visual capabilities and cortical maps in BALB/c mice. Eur J Neurosci 36: 2801-2811. CrossRef Medline

Yoon BJ, Smith GB, Heynen AJ, Neve RL, Bear MF (2009) Essential role for a long-term depression mechanism in ocular dominance plasticity. Proc Natl Acad Sci U S A 106:9860-9865. CrossRef Medline 